\title{
RANCANGAN APLIKASI ELEKTRONIK MENU RESTORAN PJ83 JAKARTA BERBASIS ANDROID
}

\author{
Aldi Aswari ${ }^{1}$, Forkas Tiroy Santos Butar-Butar ${ }^{2}$, Halimatusha'diah ${ }^{3}$ \\ Program Studi Informatika, Fakultas Teknik dan Ilmu Komputer, Universitas Indraprasta PGRI \\ Jalan Raya Tengah No 80, Kelurahan Gedong, Pasar Rebo, Jakarta Timur \\ aldiaswari6@gmail.com¹, fotysant.bb@gmail.com², halimah3186@gmail.com³
}

\begin{abstract}
Abstrak
Tujuan dari penelitian adalah untuk merancang aplikasi elektronik menu makanan restoran untuk membantu pihak restoran dalam menangani pemesanan menu makanan dan memberikan kemudahan pelanggan untuk mengetahui menu yang tersedia pada restoran sehingga tidak memerlukan waktu yang lama dalam pemesanan makanan. Dengan menggunakan firebase aplikasi pemesanan di sisi pelanggan berbasis android dapat terintegrasi dengan aplikasi restoran berbasis android untuk mengatur pemesanan. Dalam perancangan aplikasi ini, metode yang digunakan untuk menganalisis perancangan aplikasi ini adalah metode grounded yaitu metode penelitian berdasarkan pada fakta, empiris, menetapkan konsep membuktikan dan mengembangkan teori, pengumpulan dan analisis dalam waktu bersamaan. Pada hasil pengujian yang dilakukan, aplikasi elektronik menu pada restoran yang diuji dengan kuesioner. Dan peneliti menarik kesimpulan bahwa sistem yang masih konvensional berubah menjadi suatu aplikasi untuk mempermudah restoran memberikan menu yang lebih efektif. Serta melakukan data input menjadi lebih cepat, karena sistem mampu melihat menu yang dipesan oleh pelanggan.
\end{abstract}

Kata Kunci: Perancangan Aplikasi, Aplikasi Elektronik, Menu PJ83, Android

\begin{abstract}
The purpose of the research is to design the electronic application of restaurant food menu to assist the restaurant in handling the food ordering menu and provide the convenience of customers to know the menu available in the restaurant so as not take a long time in food ordering. By using Firebase the booking app on the Android-based customer side can integrate with the Android-based restaurant app to manage bookings. In designing this application, the method used to analyze the design of this application is the grounded method of research method based on the fact, empirical, establishing the concept of proving and developing theories, collection and Analysis at the same time. On the results of the test conducted, the menu electronic application in the restaurant tested with a questionnaire. And the author draws conclusions that the conventional system is transformed into an application to facilitate the restaurant provide a more effective menu. And do input data become faster, because the system is able to see the menu that the customer ordered.
\end{abstract}

Keywords: Aplication Design, Electronic Applications, Menu PJ83, Android

\section{PENDAHULUAN}

Perkembangan teknologi informasi saat ini telah memberikan pengaruh yang besar bagi dunia teknologi informasi dan telekomunikasi. Segala sesatu hal menngunakan teknologi sangat diminati oleh semua kalangan. Berbagai aktifitas mengalami perubahan dari cara yang bersifat manualmenjadi cara yang praktis dalam bentuk digital. Hal tersebut dituntut adanya perangkat elektronik yang lebih mudah bermanfaat dalam penggunaanya sehari-hari.Restoran merupakan bisnis yang sedang berkembang dan sangat diminati. Kebutuhan konsumsi akan makanan dan minuman membuat restoran bersaing member produk dan pelayanan yang terbaik kepada masyarakat. Restoran tidak lepas dari perkembangan teknologi, sebagian besar resttoran mulai menerapkan komputerisasi dalam proses bisnisnya. Namun masih terdapat aktifitas proses operasional restoran yang dilakukan secara konvesional terutama sepeti pencarian menu, dan pemesanan makanan. Proses pemesanan makanan pada suatu restoran merupakan salah satu hal yang paling penting dalam bisnis restoran. Proses pemesanan tersebut dapat dilakukan di luar lokasi restoran yang biasanya dilakukan dengan memanfaatkan pesawat telepon yang mengharuskan pelanggan untuk menyebutkan pesanan mereka secara manual. Sedangkan pencatatan pesanan pelanggan secara langsung di lokasi restoran dilakukan menggunakan alat tulis seperti pulpen dan kertas atau menggunakan komputer seperti yang terdapat 
pada beberapa restoran cepat saji. Pada sistem ini para pelanggan restoran dapat memilih menu yang sudah di tampilkan pada aplikasi Android secara langsung. Dengan pemakaian aplikasi menu ini akan memudahkan proses kerja dalam usaha restoran, dengan adanya ini pelanggan dapat melihat langsung menu pada restoran dengan mudah tanpa harus ke tempat restoran tersebut dan dapat meningkatkan pemasukan bagi restoran PJ83. Berdasarkan uraian tersebut, peneliti dalam penelitian ini akan membuat judul "Rancangan Aplikasi Elektronik Menu Restoran PJ83 di Jakarta Berbasis Android" yang dapat membantu memudahkan pelanggan dalam melakukan proses pemesanan makanan dan minuman.Perancangan adalah langkah pertama dalam fase pengembangan rekayasa produk atau sistem. Perancangan itu adalah proses penerapan berbagai teknik dan prinsip yang bertujuan untuk mendefinisikan sebuah peralatan, suatu proses atau suatu sistem secara detail yang membolehkan dilakukan realisasi fisik (Pressman, 2010). Jogiyanto menambahkan aplikasi secara umum adalah suatu proses dari cara manual yang ditransformasikan ke komputer dengan membuat sistem atau program agar dapat diolah lebih berdaya guna secara optimal (Jogiyanto, 2008). Android menyediakan platfrom terbuka bagi para pengembang untuk menciptakan aplikasi mereka sendiri untuk digunakan oleh bermacam peranti bergerak. Android umum digunakan di smartphone dan juga tanblet PC. Fungsinya sama seperti sistem operasi Symbian di Nokia, IOS di Apple dan BlackBerry OS (Nazaruddin, 2012).

\section{PENELITIAN RELEVAN}

Penelitian yang berhungan dengan perancangan aplikasi menu restoran sudah pernah dilakukan oleh beberapa peneliti diantaranya Jos Forman Tompoh dkk (2016) dalam penelitiannya ini berisi tentang pemesanan makanan yang sangat membantu para pelanggan untuk mengetahui menu yang tersedia di restoran, selain itu dapat membantu restoran dalam menangani pemesanan makanan. Perancangan aplikasi menu restoran ini menggunakan web service dan di sisi pelanggan dengan menggunakan android (client) yang dapat terintegrasi dengan aplikasi web admin di pihak restoran untuk mengatur pemesanan (server). Perbedaan objek penelitian yang kami lakukan dimana objek penelitian antara pemilik restoran dan serta para pegawai restoran (Tompoh et al, 2016).

Penelitian yang dilakukan Adi Sasongko (2007) dalam mengolah data pemesanan menu direstoran melalui pendekatan metode graunded reserch hasil penelitian didapatkan bahwa pengembangan sistem yang dibuat menjadi lebih efisien, mempertegas landasan kami dalam menggunakan metode graunded research (Sasongko, 2007).

\section{METODE PENELITIAN}

Metode penelitian yang digunakan oleh peneliti adalah metode grounded (grounded research) yaitu suatu metode penelitian berdasarkan pada fakta dan empiris, menetapkan konsep, membuktikan teori, mengembangkan teori, pengumpulan dan analisis data dalam waktu yang bersamaan. Dalam riset ini merupakan sumber teori atau teori berdasarkan data. Setelah mengumpulkan data, peneliti melanjutkan proses penelitian sesuai dengan langkah-langkah pokok yang digunakan pada metode ini, yaitu menentukan masalah yang ingin diselidiki, mengumpulkan data atau informasi yang ada di lapangan, menganalisis dan menjelaskan masalah yang ditemukan serta membuat laporan hasil penelitian sesuai dengan apa yang akan di teliti. Teknik pengumpulan data yang digunakan oleh peneliti dalam melakukan pengumpulan data :

1. Studi kepustakaan

Pengumpulan data dan informasi dari kutipan-kutipan buku-buku, peraturan perundang-undangan, serta hasil laporan dan hukum lainnya yang berkaitan dengan penelitian ini. Dari bahan-bahan tersebut di ambil teori-teori yang dapat dijadikan nlandasan untuk menganalisa masalah yang ditemukan dalam penelitian.

2. Wawancara

Dalam metode wawancara ini, peneliti dapat memperoleh data informasi langsung dari pemilik restoran PJ83 dengan cara melakukan tanya jawab dan bertatap muka langsung kepada pelaksana yang terlibat langsung dalam kegiatan pengolahan data.

3. Studi Pustaka

Sebagai pendukung dalam mencari berbagai informasi berupa teori-teori, sebagai buku refrensi yang berkaitan dengan judul penelitian. 


\section{HASIL DAN PEMBAHASAN}

Berdasarkan analisa sistem yang sedang berjalan saat ini peneliti melihat kelemahan dan permasalahan yang terdapat pada sistem daftar menu yang tersedia pada restoran PJ83, maka peneliti dapat menyarankan beberapa alternative permasalahan yang dapat dicoba, yaitu :

Membuat perancangan aplikasi elektronik menu untuk mempermudah pelanggan dalam mengetahui menu yang tersedia pada restoran dan memudahkan pelanggan melakukan pemesanan.

Merancang aplikasi dengan pemilihan penggunaan koneksi Internet dibandingkan dengan penggunaan Bluetooth adalah karena beberapa alasan, seperti transfer rate yang lebih cepat dibandingkan dengan penggunaan Bluetooth. Proses pembuatan laporan setelah adanya perancangan aplikasi elektronik menu menjadi lebih efesien dan efektif. Use Case Diagram sistem pemesanan yang diusulkan pada Restoran PJ83 dapat di gambarkan sebagai berikut:

\section{Use Case Diagram}

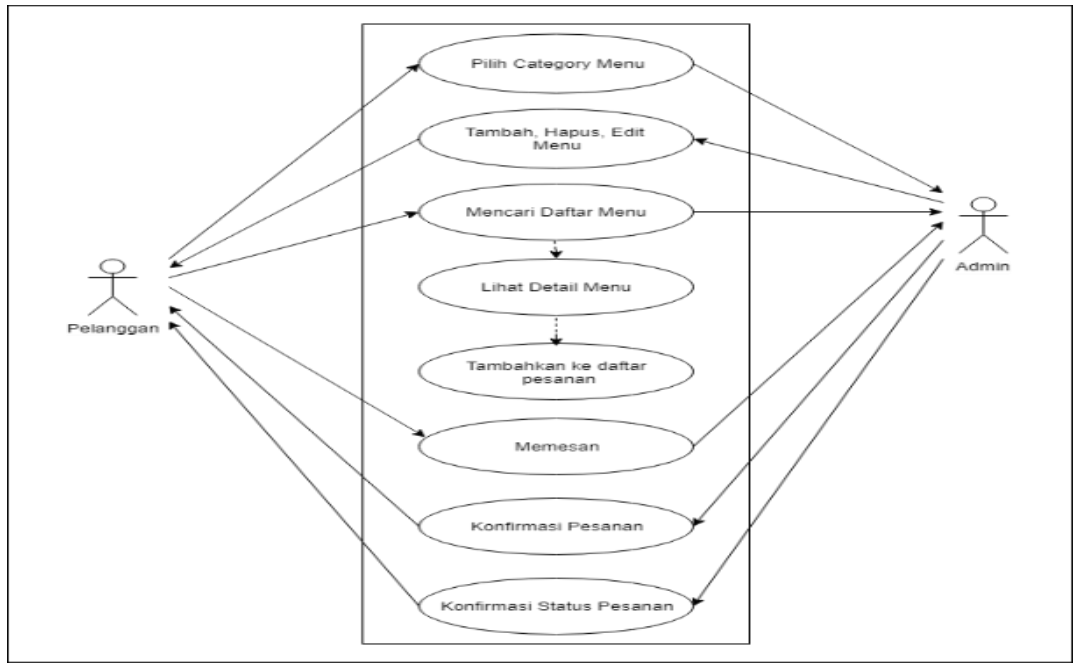

Gambar 1. Use Case Diagram

\section{Activity Diagram}

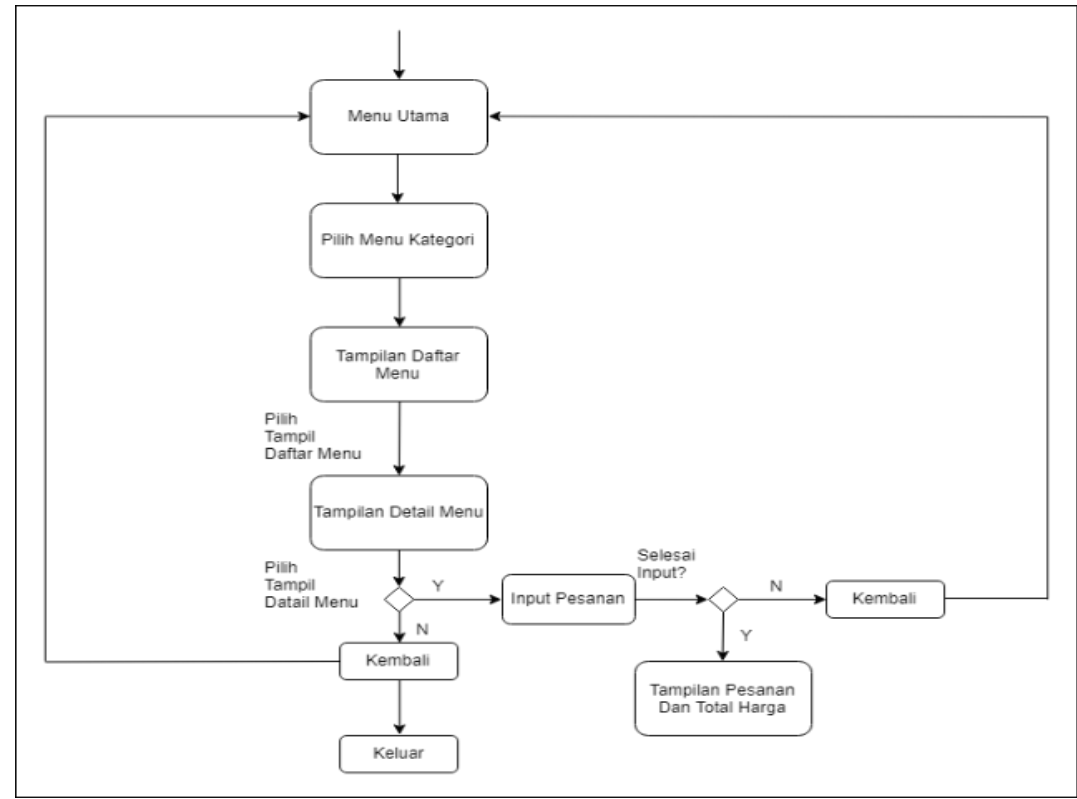

Gambar 2. Activity Diagram 
JRAMI (Jurnal Riset dan Aplikasi Mahasiswa Infarmatika)

Vol 이 № 02 Tahun 2020

e-ISSN : $2715-8756$

\section{Class Diagram}

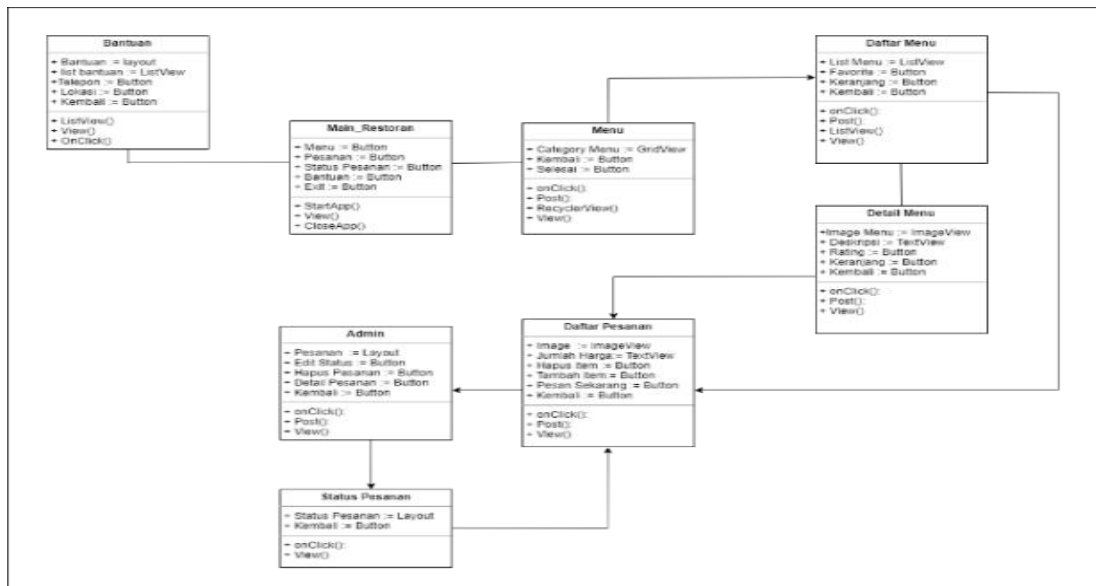

Gambar 3.Class Diagram

\section{Sequance Diagram}

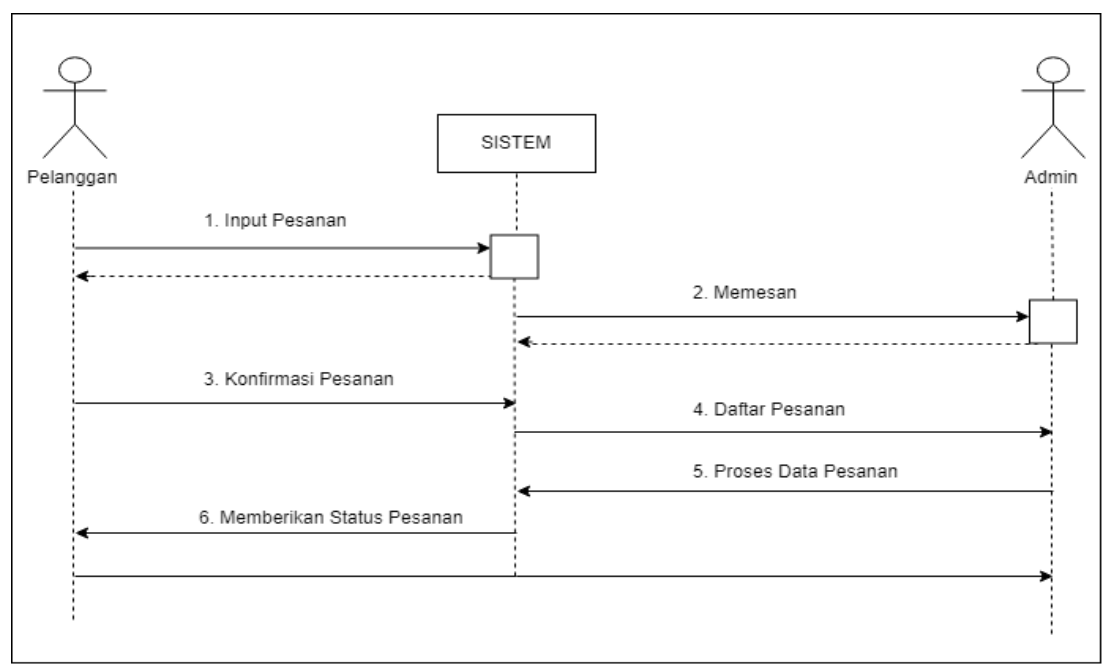

Gambar 4. Sequance Diagram

\section{Tampilan Aplikasi Pelanggan}

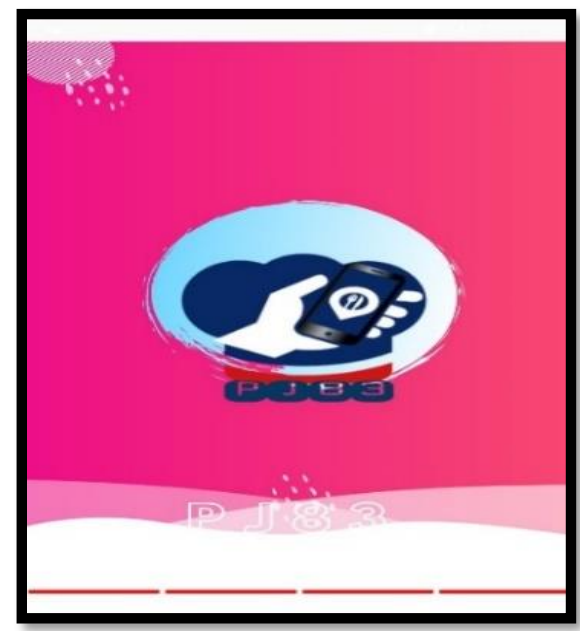

Gambar 5. Tampilan Splash Screen 
Pada Gambar 5 menampilkan splashscreen untuk membuka menu awal menunjukkan tampilan splashscreen yang berjalan baik pada smartphone android.

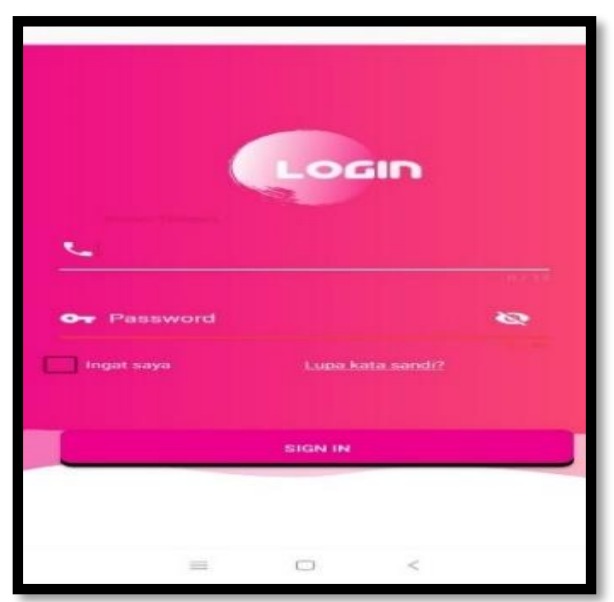

Gambar 6. Tampilan Login

Pada Gambar 6 menampilkan tampilan untuk masuk ke aplikasi menu restoran dengan mengisi nomor telepon dan password.

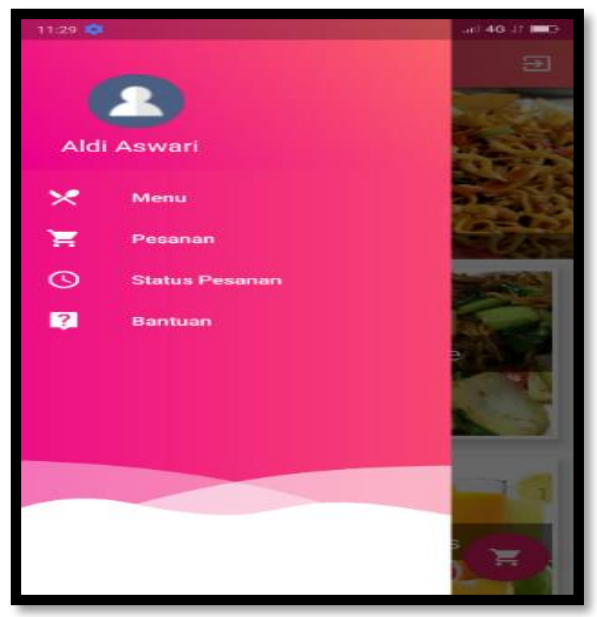

Gambar 7. Tampilan Menu Utama

Pada tampilan Gambar 7 ini menampilkan empat sub menu yang terdiri dari menu, pesanan, status pesanan dan bantuan.

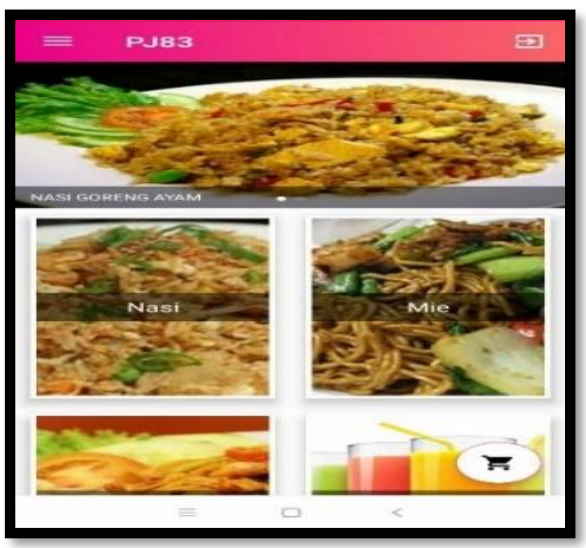

Gambar 8. Tampilan Menu Kategori 
Setelah user memilih kategori menu di halaman awal, maka akan tampil nama menu yang tersedia. Tampilan terbentuk listview dan terdapat scrool atas dan bawah.

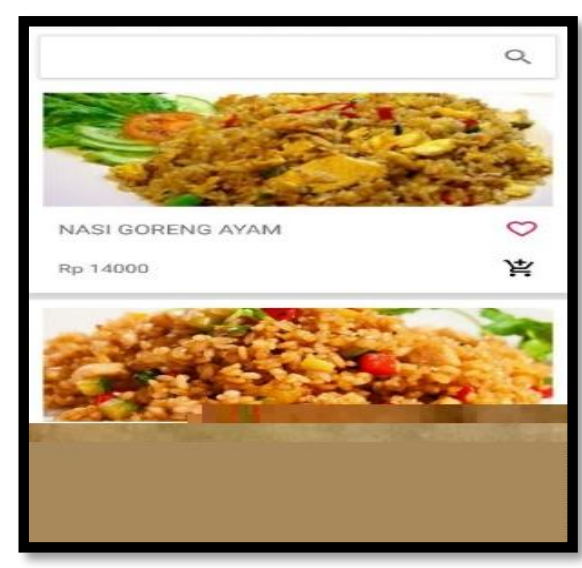

Gambar 9. Tampilan List Menu

Tampilan ini menampilkan menu yang di pilih dan bisa langsung mencari makanan yang diinginkan dengan mengunakan fitur pencarian dan terdapat tombol Favorite untuk menyimpan menu yang disukai.

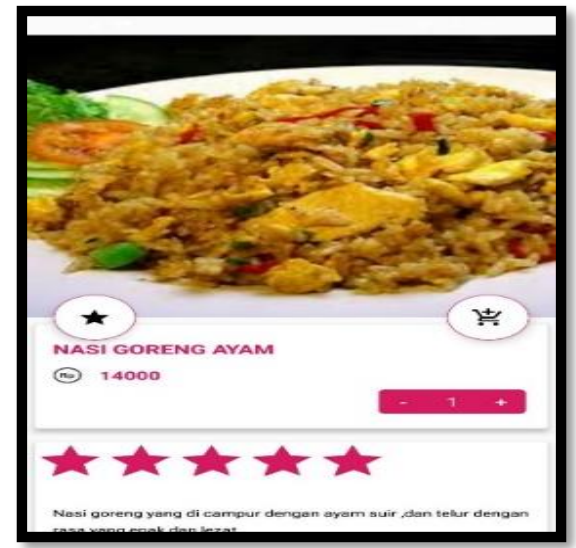

Gambar 10. Tampilan Detail Menu

Halaman ini memiliki dua tombol yaitu tombol keranjang menambahkan menu ke daftar pesanan dan tombol rating. Jika pilih Kembali maka akan membawa panggilan ke halaman daftar menu.

\section{Tampilan Aplikasi Admin}

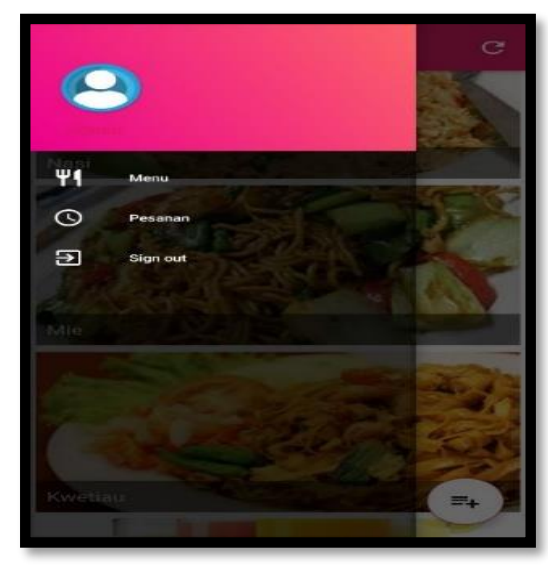

Gambar 11. Tampilan Splash Screen 
JRAMI (Jurnal Riset dan Aplikasi Mahasiswa Infarmatika)

Vol OI No QZ Tahun ZQZО

e-ISSN : $2715-8756$

Pada tampilan ini menampilkan tiga sub menu yang terdiri dari menu, pesanan dan sign out .

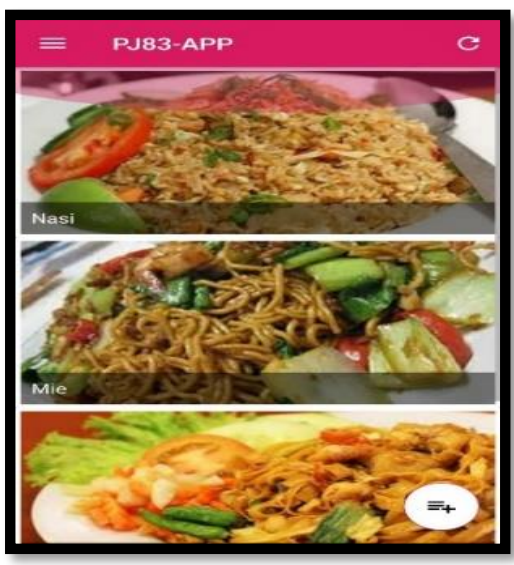

Gambar 12. Tampilan Menu Kategori

Pada Gambar 12 menampilkan dialog update menu category, terdapat tombol pilih dan upload untuk menambahkan gambar yang ingin diupdate, jika sudah update menu category lalu klik tombol ok untuk melakukan penyimpanan menu yang di update.

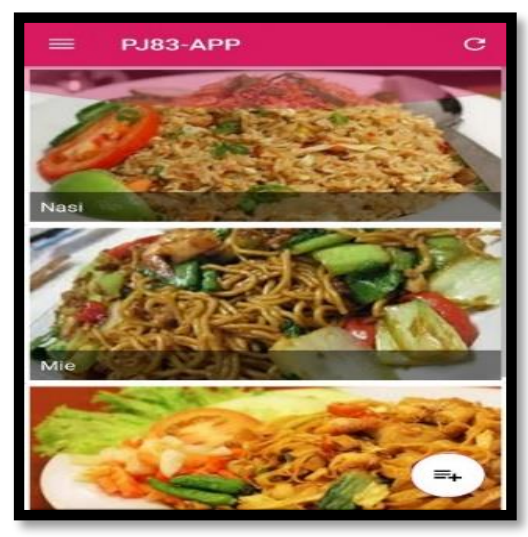

Gambar 13. Tampilan Tambah Menu

Setelah user memilih kategori menu di halaman awal, maka akan tampil nama menu yang tersedia. Tampilan terbentuk listview dan terdapat scroll atas dan bawah, jika menekan category menu maka akan keluar dialog update dan hapus.

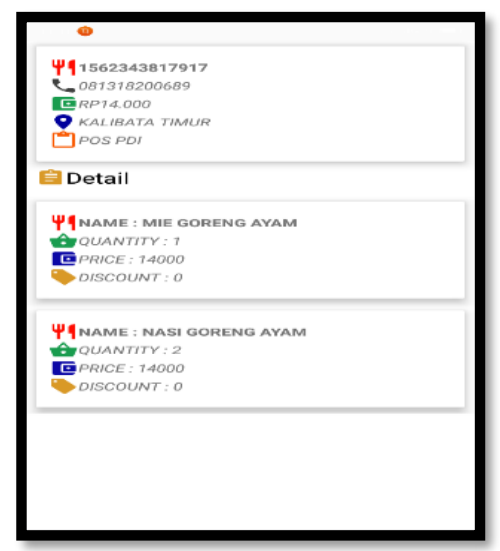

Gambar 14. Tampilan Detail Pesanan 
Pada Gambar 14 menampilkan detail makanan, harga, nama pemesan serta keterangan yang di pesan oleh pelanggan.

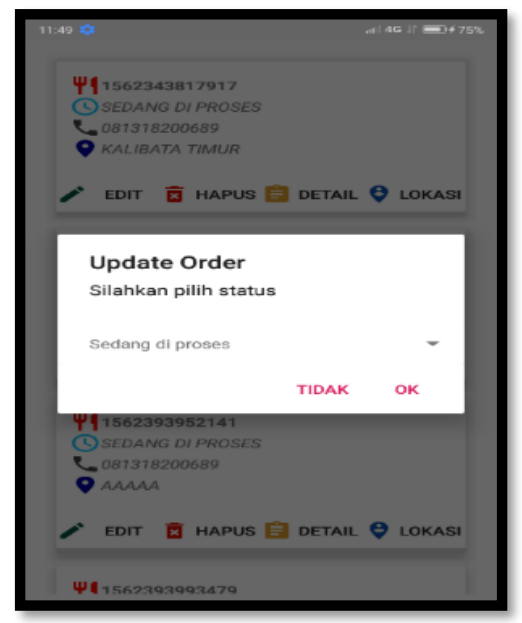

Gambar 15. Tampilan Update Pesanan

Pada tampilan ini menampilkan detail makanan, harga, nama pemesan serta keterangan yang di pesan oleh pelanggan.

\section{SIMPULAN}

Berdasarkan analisa yang telah di uraikan dari bab sebelumnya, maka dapat disimpulkan perihal Perancangan Aplikasi Elektronik Menu sebagai berikut :

1. Aplikasi ini dapat mengatasi banyaknya masalah pemesanan makanan dan minuman dengan platform Android.

2. Aplikasi ini bisa langsung memberitahu pesanan pelanggan ke bagian admin yang membuat pekerjaan bisa menjadi lebih cepat.

\section{DAFTAR PUSTAKA}

Jogiyanto, H. (2008). Analisis dan desain. Yogyakarta. Sistem Informasi Manajemen Jogiyanto H.M. Analisa Dan Desain. Ladjamudin, A. B. B (2012). Rekayasa Perangkat Lunak. Yogyakarta: Penerbit Graha Ilmu.

Pressman, R. S. (2010). Rekayasa Perangkat Lunak: Pendekatan Praktisi. In Software Engineering A Practitioner's Approach 7th Ed - Roger S. Pressman. https://doi.org/10.1017/CBO9781107415324.004

Sasongko, A. (2010). Aplikasi pemesanan makanan dan minuman pada rumah makan. 18. Retrieved from http://www.gunadarma.ac.id/library/articles/graduate/computer-science/2007/Artikel_10102100.pdf

Tompoh, J. F., Sentinuwo, S. R., \& Sinsuw, A. A. E. (2016). Rancang Bangun Aplikasi Pemesanan Menu Makanan Restoran Berbasis Android. Jurnal Teknik Informatika, 9(1), 1-9. https://doi.org/10.35793/jti.9.1.2016.13749 